Thursday, 19th November 1868.

James Gowans, Esq., Vice-President, in the Chair.

The following Gentleman was elected an Ordinary Fellow of the Society:-

Edward Brown, Arthur Lodge, Edinburgh.

An address on "Field Work, its Charms and Instructions," was delivered by D. Page, LL.D.

\title{
Excerpt therefrom.
}

In retiring from this chair, I have no difficulty in finding a subject whereon to offer a few parting words to the Fellows of the Edinburgh Geological Society. During the last seven years the Society has made great and gratifying progress. From less than fifty members it has now risen to more than two hundred. But though strong in numbers, I fear it is still somewhat weak in workers. It is true we have established a Museum, inaugurated a Library, and commenced to publish Transactions. But though thus assuming all the functions of a well-appointed society, these functions have as yet been very slenderly performed. These appointments, however valuable as adjuncts to a working society, will at most be little better than dross and rubbish if we seek not to exhibit the real metal which comes alone from an active and earnest working in the field of observation. We may add member to member, and these we value as showing an interest in our especial study, or as showing their willingness to aid us with their contributions; but though we were to add double their number, it would be no security for the permanence of our Society and its progress, unless a large number betake themselves to the practice of the science, and become field-observers. There is none of us but has now and again his day of leisure, his excursion to the country, or his few weeks of summer holiday; and unless this time be spent so far in the delightful exercise of observation, and in bringing this observation before his fellow-members, he neglects his opportunities as regards the science, and fails to fulfil his obligations to the Society. No one will ever arrive at true conceptions of world-history unless through the immediate study of the leaves on which that history is recorded. Travel and observation are the prime essentials of the science, and he who foregoes these-to the extent of his opportunity-omits the main chance of understanding aright its numerous and complicated problems. "To the field on every fitting occasion" should be the guiding maxim of the young geologist; and though new discoveries may not always reward 
his toil, though he should even fail to obtain what others have obtained before him, he is at least in the way of doing both; and in the excellent practice of training his powers of observation. And when his day's work is done, however little it may have added to his scientific stores, he has secured one luxury, at least, by his twenty miles' ramble in the pure country air-a blessing which comes to the poor unasked, and which the rich but too seldom enjoy-the luxury of feeling tired.

\section{Thursday, 3d December 1868.}

Archibald Geikie, Esq., F.R.S., President, in the Chair.

On taking the chair as President of the Society Mr Geikie delivered an address, of which the following is an abstract:-

After thanking the Society for the compliment which they had paid him in electing him their President, he passed on to notice some of the functions of scientific societies. These societies, he said, may be conveniently divided into two classes-first, those of a national character, like the Royal Society, the Geological Society, and the Chemical Society of London ; and second, local societies, properly so-called. The functions of a local society are five-fold,-first, to exhaust, so far as possible, the geology, botany, or natural history, as the case may be, of its own district, and to methodise and encourage the observations of an organised body of workers among its members; secondly, to watch every change within the scope of its own science which may arise in the course of human progress-for example, in botany, to note the changes caused by man's interference upon the plants of a district; in geology, to notice the effects revealed by every new quarry, railway cutting, or exposure, along with the influence of man upon existing geological process; third, to bring forward at evening meetings notices of all new observations made by the members or by others in the district, and to preserve, and where possible, publish a record of these observations; fourth, to aid the researches of men who are devoting themselves to any special branch of science, by furnishing them with carefully verified facts and specimens, or other material which may be required; and fifth, to foster among its own members and in the outer world a love of the science which the Society is specially formed to cultivate. In regard to the Edinburgh Geological Society, the author pointed out how advantageously situated it is for the study of geological science. No better field for the prosecution of that study can be found than the neighbourhood of Edinburgh, while the libraries and geological collections in the city afford excellent help to the 